\title{
Demographic and socio-economic factors influencing health inequalities in the Czech Republic
}

\author{
Dana Hübelová ${ }^{1 凶}-$ Pavel Ptáček ${ }^{1}$ - Tereza Šlechtová ${ }^{1}$ \\ ${ }^{1}$ Department of Social Studies, Faculty of Regional Development and International Studies, Mendel University in Brno, Czechia \\ $\bowtie$ dana.hubelova@mendelu.cz
}

\begin{abstract}
Health inequalities, which could be prevented by appropriate means in various areas, are generally perceived as a consequence of injustice in the society and are mostly the result of inequalities in social determinants. The main goal of this article is to determine health inequalities defined by demographic and socio-economic factors at the level of districts of the Czech Republic in the period 2007-2018(due to the specific differences in data, the Capital City of Prague region was not included). The following statistical methods were used to process the data: correlation analysis, principal component analysis, composite indicator, cluster analysis and multidimensional factor analysis. The value of the composite indicator shows a very favorable situation in the districts of Praha-východ and Praha-západ (especially high proportion of university students, low unemployment, age index, infant mortality, abortion rate and housing subsidies), and the unfavourable situation in the districts of Chomutov, Teplice and Most (especially high housing and unemployment subsidies, low rate of university students, negative migration balance, high rates of infant mortality and abortion). The results specify regional disparities of demographic and socio-economic indicators that can cause health inequalities: negative regional disparities (Most, Teplice, Děčín, Bruntál, Karviná, Ostrava-město and Jeseník districts) and positive regional disparities (Praha-západ, Praha-východ, Mladá Boleslav, Jihlava and Brno-venkov). The study presents the results of analyses based on the example of smaller territorial units (districts) and confirms the existence of regional disparities in accordance with research at the national and international level.
\end{abstract}

\section{Highlights for public administration, management and planning:}

- Demographic factors are connected to socio-economic environmental factors (poverty, education, social exclusion, unemployment, social security, family situation etc.) that lead to regional health inequalities.

- The regional disparities of selected demographic and socio-economic indicators of the districts of the Czech Republic that cause health inequalities were specified.

\section{Keywords}

Health inequalities,

Demographic and socio-economic factors,

Regional disparities, Cluster analysis

Received: 23 October 2020

Received in revised form: 04 March 2021

Accepted:

22 April 2021

\section{Introduction}

The first conceptual framework for a holistic understanding of health as a result of not only genetic and environmental factors, but also the influences of lifestyle or health care organizational structure, can be considered the Canadian Health Report A new perspective on the health of Canadians (Lalonde 1974). With regard to the researched issue, it is important to distinguish between health inequality and health inequity. The first concept (health inequality), which is the subject of the presented study, refers to differences in health and the measurable aspect of health, which differs in the population, can be called health inequalities. Conversely, the second concept (health inequity) indicates inequitable difference in health (Kawachi et al. 2002). The last three decades have seen a worldwide increase in interest in the study of health inequalities, especially since the establishment of the Commission on Social Determinants of Health (CSDH) in 2005. CSDH has begun to gather global evidence on health inequalities and report on ef- 
fective measures to address "preventable health inequalities" (CSDH 2008). This CSDH approach focuses mainly on the perspective of social determinants of health and has provided a necessary alternative to the biomedical and individual determinants of health inequalities (Cash-Gibson et al. 2018). In recent years, there has been an increase in research, which shows that systematic differences in the health status of the population, which can be prevented, exist both between and within societies, at all hierarchical levels (i.e. countries, regions, areas, etc.; Ottersen et al. 2014). Demographic and socio-economic factors of health are related to the lifestyle of individuals, their social community and social strata. Factors affecting health are often associated with poor physical condition, both physical and mental, leading to inequalities in the health of the population, the emergence of disease and premature death (Marmot \& Bell 2012).

\section{Selected demographic and socio- economic factors of health}

Social Sciences deal with the topics of social inequalities in health, the links between health and values, the consequences of changes in health policies, etc. (Saks \& Allsop 2013: 6-7). Despite a comparable standard of living and almost universal healthcare provision, there are significant health inequalities in the European Union (EC 2013). After taking into account the factors at the macro level, more than half of the variation remains unexplained and this is the reason to examine the differences in demographic and social characteristics (Mazeikaite et al. 2021). According to experience, however, not all of the used indices of social deprivation can be applied in the Czech Republic (e.g. Townsend's index of deprivation), because Czech society is levelled in many respects and individual social strata are not strictly distinguished by status features (Mareš 1999). However, the analysis of status consistency proves that the dominant factor is usually formed by three status-forming variables, namely education, employment and income (Matějů \& Kreidl 1998; Večerník \& Matějů 1998; Tuček et al. 2008).

The influence of demographic and socio-economic factors on health is currently considered to be factually proven (Marmot \& Bell 2012). Demographic and socio-economic indicators use more extensive national and international comparative studies of health and health status (Börsch-Supan et al. 2013; Minicuci et al. 2016). Due to the large num- ber of these factors, we decided to deal in this article - both in the theoretical background and in the analytical part - with only selected factors and their impact on health which is already sufficiently clarified in the literature and studies. Selecting relevant indicators, we have also used our own research experience (Hübelová et al. 2018; 2020a; 2020b; 2021; Hübelová \& Kozumplíková 2019).

The basic demographic indicators include gender and age, from which the age index is derived as the ratio of the pre-productive and post-productive components of the population. The age composition of the population not only shapes the current health status of the population and its previous development, but also strongly influences the future status and ways of interventions in its determinants (Srivarathan et al. 2019). The basic feature of development of the population in the Czech Republic, as in all developed countries, is the aging population, which results in changes in the age groups. In the future, the group is expected to grow in the age category of 65 and over in a $31 \%$ share of the total population in 2040 and up to $36 \%$ representation in 2065. The numerical size of the post-productive age category should thus increase to 3 million inhabitants in 2030 and to 3.5 million inhabitants in 2065, when it will most likely culminate (Burcin \& Kučera 2004).

Life expectancy is one of the important synthetic demographic indicators, which is currently considered the most accurate indicator of the mortality rate. Life expectancy can also be seen in a broader context as a key indicator of the quality of life, wellbeing and health of a population or a region, as it reflects social and economic conditions and the quality and availability of public health and healthcare infrastructure (Ho \& Hendi 2018). The indicator of spontaneous abortion can be considered a complex indicator of health determinants, especially in women. Infant mortality reflects the standard of living and quality of health care (Tomulic et al. 2017). As in the case of spontaneous abortion, the infant mortality rate tends to decrease with increasing levels of parental education (Son \& Lee 2011). Infant mortality captures both the health status of the population and socio-economic conditions and is influenced by the region's GDP, education and socio-economic status of parents, as well as the age of the mother, etc. (Tavares 2017).

A number of studies document the effect of divorce on health, resp. personal well-being and lifestyle. Thus, it is possible to state the specific consequences of divorce on the later behavior of children and adolescents in terms of substance use, especially tobacco smoking and alcohol consumption. 
Specifically, results in the US show that adults, who have experienced parental divorce during childhood will be 1.5 times more likely to smoke cigarettes and more probable alcohol drinkers in adulthood than those who have not experienced divorce (Demir-Dagdas 2020). Data from The Health and Retirement Study present a link between divorce and health in middle and later life, where divorce is more often associated with adverse changes in physical and mental health, especially in women (Zulkarnain \& Korenman 2019). Divorced or separated people are generally less satisfied with life and have lower physical activity and a risk of impaired health test results, including a 23\% higher probability of mortality, with approximately $10-15 \%$ of divorcees subject to long-term overall increased adverse health risk (Sbarra 2015).

On one hand, migration contributes to the wealth of the economy, on the other hand, it contributes to health inequalities between migrant and permanent populations, caused by different exposure to wider social determinants of health (Chung \& Griffiths 2018). Housing subsidies paid out are considered a suitable indicator of socioeconomic status. Income levels, employment, material poverty, housing standards, change in social status etc. can be reflected in the level of health and can also be a source of various health risks (Pinto et al. 2016). Unemployment is a highly stressful life event that affects not only mental but also physical health (Norstrom et al. 2019). Long-term unemployment is reflected in nervous system dysfunction as well as physical disorders. Psychosomatic disorders include a higher probability of cardiovascular, respiratory, etc., as well as premature mortality (Zenger et al. 2013). Incapacity for work also has negative socioeconomic consequences for individuals and society. It should be considered that the link between work and health is two-way: health affects the nature of work and at the same time the choice of occupation is closely linked to a number of demographic and social factors (e.g. direct link to education level). Work and employment themselves affect individuals and groups of people through material and psychosocial factors, such as occupational risks to workers' physical or mental health, which can result in functional impairment and disability (Bültmann et al. 2020).

Urbanization can have an impact on the health of urban dwellers, especially in the context of environmental health (Lakes et al. 2014); although historically urbanization has been associated with positive economic development and higher quality of health, as cities generally offer better hygiene, education and employment opportunities, available infrastructure and health services (Fraser \& George 2015). However, the current process of urbanization is completely different and these changes simultaneously cause increasing morbidity, mortality and changes in physical and mental health (Li et al. 2016). Another feature of urbanization is increased road traffic, increased concentrations of greenhouse gases, emissions and immissions, noise, dust, etc., which worsens the symptoms of asthma and can lead to impaired lung function (chronic obstructive pulmonary disease, neoplasm, etc.), cardiovascular disease, unhealthy aging (Giles-Corti et al. 2016) and the risk of premature mortality (Landrigan et al. 2018).

Educational attainment is one of the best achievable indicators of socio-economic status (Pruchno et al. 2010). There are a large number of so-called causal chains that explain the impact of education on health, in which there are still many unknowns, however, it is possible to distinguish two groups of these chains (Ljungdahl \& Bremberg 2015). In the first, education improves the "absolute" competence of the individual, so it can increase his individual ability to use and interpret information and translate the acquired knowledge into practice, including any practice to promote health. The effect of education in this case manifests itself as strengthening individual "health efficiency" (Mirowsky \& Ross 2003). In the second "relative" causal chain, education provides individuals with skills that they can use to compete with other individuals. Higher (longer) level of education thus increases opportunities for better employment with higher financial rewards and social. There has been a clear positive link between education and health, as people with a university degree are less likely to suffer from a chronic illness (Cutler \& LlerasMuney 2006).

\section{Objectives of the work, methods and indicators}

The main goal is to determine health inequalities defined by demographic and socio-economic factors at the level of districts of the Czech Republic in the period 2007-2018. The main goal is achieved by gradually solving partial goals: (1) to find out which districts show similar or different characteristics of demographic and socio-economic development and (2) to specify regional disparities of demographic and socio-economic indicators causing health inequalities. 


\section{sciendo}

Data from the public database of the Czech Statistics Office (CZSO) and the Institute of Health Information and Statistics of the Czech Republic (IHIS $\mathrm{CR}$ ) were used for the analysis. The data were collected from 76 districts of the Czech Republic (LAU 1). Due to extreme values and the avoidance of remoteness of values, which would significantly affect the statistical processing, the district of the Capital City of Prague was excluded from the database. The relevant data were processed in the STATISTICA 12 programme and selected results were visualized in the ArcGIS 10.6 programme.

A number of statistical methods were used to process the data. Correlation analysis determined the strength of the linear relationship between the quantities using Pearson's correlation coefficient (r). For the value of $r$, the type of dependence applies: $0.00-0.19$ "very weak"; 0.20-0.39 "weak"; 0.40-0.59 "medium"; 0.60-0.79 "strong"; 0.80-1.00 "very strong". The principal component analysis method was used to reduce the number of interrelated variables. The number of main components was determined according to the given criteria: the number of independent values of components was greater than 1 , only so many components were used that describe $90 \%$ of the original variables and according to the scree graph a break point of rapid descent to gradual was found (Meloun et al. 2017).

The creation of a composite indicator (composite indicator; CI) made it possible to summarize multidimensional phenomena using sub-indicators. CI was composed of partial indicators (sub-indicators) of the min-max type. The individual sub-indicators were not assigned values in order to avoid biased emphasis on any of them. Using standardization, the original values of the sub-indicators were transformed into dimensionless, easily aggregated quantities. The min-max method transforms the original scale into a hundred-point scale0;100. The following applies to indicators (Minař́k et al. 2013): type max is converted by the formula

$$
B_{j}=\frac{X_{j}-\min \left\{X_{j}\right\}}{\max \left\{X_{j}\right\}-\min \left\{X_{j}\right\}}
$$

type min is converted by the formula

$$
B_{j}=\frac{\max \left\{X_{j}\right\}-X_{j}}{\max \left\{X_{j}\right\}-\min \left\{X_{j}\right\}}
$$

Further, the CI itself was created using the weighted sum method, which can also be expressed relatively, in the form of an index in relation to its average value (Minař́k et al. 2013).
Spatial aspects of the monitored indicators were evaluated using cluster analysis. The method of hierarchical clustering was chosen. The first step of cluster analysis was to calculate the distance of objects and store the matrix of distances (the distance between objects was defined using the Euclidean distance; Minař́k et al. 2013). The association of objects into clusters was determined on the basis of a matrix of distances using clustering algorithms of the Ward method. The resulting graph of cluster analysis is the so-called dendrogram, in which it is true that cases that are similar will be in the same or close cluster, and conversely different will be far apart (Hübelová et al. 2020). Multivariate factor analysis was used to determine the dependence (correlation) and to reveal the basic structure and internal relationships of the source data matrix. Factor analysis assumed non-zero correlations. The first step in factor analysis was to estimate the factors using the principal components method, which produces factors that are also principal components. The second step is the socalled rotation of factors using the Varimax method, in which the factor coordinates were rotated so as to create an understandable correlation structure. The interpretation of factors was determined from correlations with input variables - factor loads (Meloun et al. 2017).

For the evaluation of regional health inequalities in the districts of the Czech Republic, we have chosen such indicators for the demographic and socioeconomic area, which can be considered as those that either directly or indirectly affect the quality of health and health status of the population (Table 1).

Table 1 Selected sub-indicators variables of health inequalities

\begin{tabular}{lcc}
\hline \multicolumn{1}{c}{$\begin{array}{c}\text { Sub-indicator/ } \\
\text { Variable }\end{array}$} & $\begin{array}{c}\text { Measurement unit/ } \\
\text { Dimension }\end{array}$ & $\begin{array}{c}\text { Research } \\
\text { period }\end{array}$ \\
\hline Age index & $\%$ & \\
Life expectancy at birth & in years & \\
Proportion of abortions & $\%$ & $2007-2018$ \\
Infant mortality & $\%$ o & \\
Share of divorces & $\%$ oo & \\
Migration balance & CZK/persons & \\
Housing allowances & $\%$ & 2011 \\
Share of unemployed & No of days \\
Incapacity for work & $\%$ & \\
Share of urban population & $\%$ & \\
\hline Share of university graduates & & \\
\hline
\end{tabular}




\section{Results - evaluation of demographic and socio-economic indicators}

Based on the compiled $\mathrm{CI}$, the value of the index of the demographic and socio-economic situation in the districts has been determined. The situation in the districts of Praha-západ and Prahavýchod proved to be the most favourable, and vice versa the least favourable in the districts of Most and Teplice (Table 2).

The districts have been further divided into groups according to the index values. The proposed division has been realized by means of legend intervals in the form of a natural grouping of values (natural breaks) in the ArcGIS programme. The groups have been assigned characteristics based on a following scale: districts with a very high - high - average low - very low index value (Fig. 1).

The districts of Chomutov, Louny, Most, Teplice, Ústí nad Labem, Děčín, Bruntál, Karviná and Sokolov reach very low CIs. On average, in the period from 2007 to 2018, the highest housing allowances were recorded in these regions, especially in the Most districts (CZK 1613/person) and Karviná (CZK 1364/person). At the same time, these districts faced the highest average share of unemployed people: Most district (11.1\%) and Bruntál (10.9\%) and show a high share of urban population: Most district (90.6\%) and Karviná (87.6\%). This group of very low CI values is dominated by districts located mainly in the Ústí nad Labem and Moravian-Silesian regions, which are also characterized by a below-average educational structure due to the low share of university students: Sokolov district (5.2\%) and Děčín (6.1\%). Conversely, abortion rates and infant mortality rates are high. The Teplice district has an abortion rate of $51.2 \%$ and Chomutov $49.2 \%$. Infant mortality in the districts of Most and Louny was around 5\%. The population in this group lives to a rather belowaverage age expressed by valuable life expectancy at birth: Teplice district (75.3 years) and Karviná (76.0 years). It can be concluded that, among other things, as a result of the above circumstances, the migration balance in the districts of the group was negative. In summary, these districts are showing as negative (differences in phenomena and processes) within the Czech Republic, due to their economic, social and ecological development of the region (Kutscherauer et al., 2008).
Table 2 Final ranking of districts of the Czech Republic according to the index of demographic and socio-economic development (average of the period from 2007 to 2018)

\begin{tabular}{|c|c|c|c|c|c|c|c|}
\hline 离 & 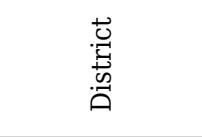 & $\vec{\nabla}$ & 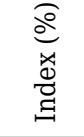 & 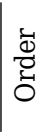 & 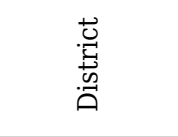 & $\sqrt{2}$ & $\frac{\underbrace{0}}{\stackrel{0}{0}}$ \\
\hline 1 & Praha-západ & 86,4 & 167,1 & 39 & Liberec & 52,8 & \\
\hline 2 & Praha-vých & 81,8 & 158,1 & 0 & & 2,7 & \\
\hline 3 & Pardubice & 70,3 & 135,8 & 41 & Opava & 52,5 & \\
\hline 4 & $\begin{array}{l}\text { Mladá } \\
\text { Boleslav }\end{array}$ & 70,2 & 135,6 & 42 & Břeclav & 51,7 & 99,9 \\
\hline 5 & $\begin{array}{l}\text { Rychnov } \\
\text { nad Kněžnou }\end{array}$ & 66,5 & 128,6 & 43 & Chrudim & 51,6 & 99 \\
\hline 6 & Jihlava & 66,0 & 127,6 & 44 & Plzeň-jih & 51,6 & 99,7 \\
\hline 7 & Brno-město & 65,9 & 127,5 & 45 & $\begin{array}{l}\text { Uherské } \\
\text { Hradiště }\end{array}$ & 51,1 & 98 \\
\hline 8 & Brno-venkov & 65,7 & 127,0 & 46 & Přerov & 51,0 & \\
\hline 9 & $\begin{array}{l}\text { Ždár } \\
\text { nad SázaI }\end{array}$ & 64,0 & 123,8 & 47 & Prostějov & 50,3 & 97 \\
\hline 10 & Vyškov & 62,4 & 120,6 & 48 & Rakovník & 50,2 & \\
\hline 11 & $\begin{array}{l}\text { Hradec } \\
\text { Králové }\end{array}$ & 62,2 & 120,3 & 49 & Svitavy & 50,0 & 96,7 \\
\hline 12 & Ústí nad C & 61,7 & 119,4 & 50 & Strakonice & 49,8 & \\
\hline 13 & Nymburk & 60,9 & 117,7 & 51 & Kutná Hora & 49,4 & \\
\hline 14 & $\begin{array}{l}\text { Čes } \\
\text { Bud }\end{array}$ & 60,2 & 116,3 & 52 & Tachov & 49,4 & 95 \\
\hline 15 & Plzeň-mé & 60,0 & 116,0 & 53 & Hodonín & 48,4 & 93 \\
\hline 16 & $\begin{array}{l}\text { Havlíćkův } \\
\text { Brod }\end{array}$ & 59,9 & 115,8 & 54 & $\begin{array}{l}\text { ký } \\
\text { nlov }\end{array}$ & 47,8 & 92 \\
\hline 17 & Třebíč & 59,6 & 115,2 & 55 & cany & 47,2 & \\
\hline 18 & Jičín & 3,9 & 113,9 & 56 & & 6,8 & \\
\hline 19 & Olomouc & 58,5 & 113,1 & 57 & & 6,5 & \\
\hline 20 & Dor & 58,0 & 112,0 & 58 & & 6,3 & 89 \\
\hline 21 & Bla & 57,8 & 111,7 & 59 & & 5,9 & 88 \\
\hline 22 & Beroun & 57,5 & 111,1 & 60 & ípa & 44,1 & 85,3 \\
\hline 23 & Mělník & 57,4 & 111,0 & 61 & & 44,1 & 85,2 \\
\hline 24 & Koll & 7,2 & 110,7 & 62 & něřice & 3,9 & \\
\hline 25 & Ser & 7,1 & 110,4 & 63 & $\mathrm{Ka}$ & 43,1 & 83,2 \\
\hline 26 & Benešov & 56,5 & 109,2 & 64 & Che & 42,1 & 81 \\
\hline 27 & Pelhřimo & 56,0 & 108,3 & 65. & & 41,0 & 79,3 \\
\hline 28 & $\begin{array}{l}\text { Jindřichův } \\
\text { Hradec }\end{array}$ & 56,0 & 108,2 & 66 & Šumperk & 40,6 & 78,6 \\
\hline 29 & Plzeň-sever & 55,9 & 108,2 & & $\begin{array}{l}\text { Ostrava } \\
\text {-město }\end{array}$ & 36,5 & 70 \\
\hline 30 & Tábor & 55,8 & 107,9 & & Sokolov & 32,8 & 63,4 \\
\hline 31 & Zlín & 55,4 & 107,2 & 69 & $\begin{array}{l}\text { Ustí } \\
\text { nad Labem }\end{array}$ & 31,8 & 61,4 \\
\hline 32 & & & 106,3 & 70 & Bruntál & 30,4 & \\
\hline 33 & &, 9 & & 71 & & 0,2 & 58 \\
\hline 32 & & 54,8 & & 72 & & 29,1 & 30 \\
\hline 35 & & 54,6 & & & & 28,4 & \\
\hline 36 & Frýdek-Místek & 53,8 & 104,0 & & Chomutov & 27,3 & 52,8 \\
\hline 37 & & & & 75 & Tep & 23,6 & 45 \\
\hline 38 & Př́ibram & 53,2 & 102,9 & 76 & Most & 17,7 & \\
\hline
\end{tabular}

CZSO: data (2019b), own calculation and data processing 


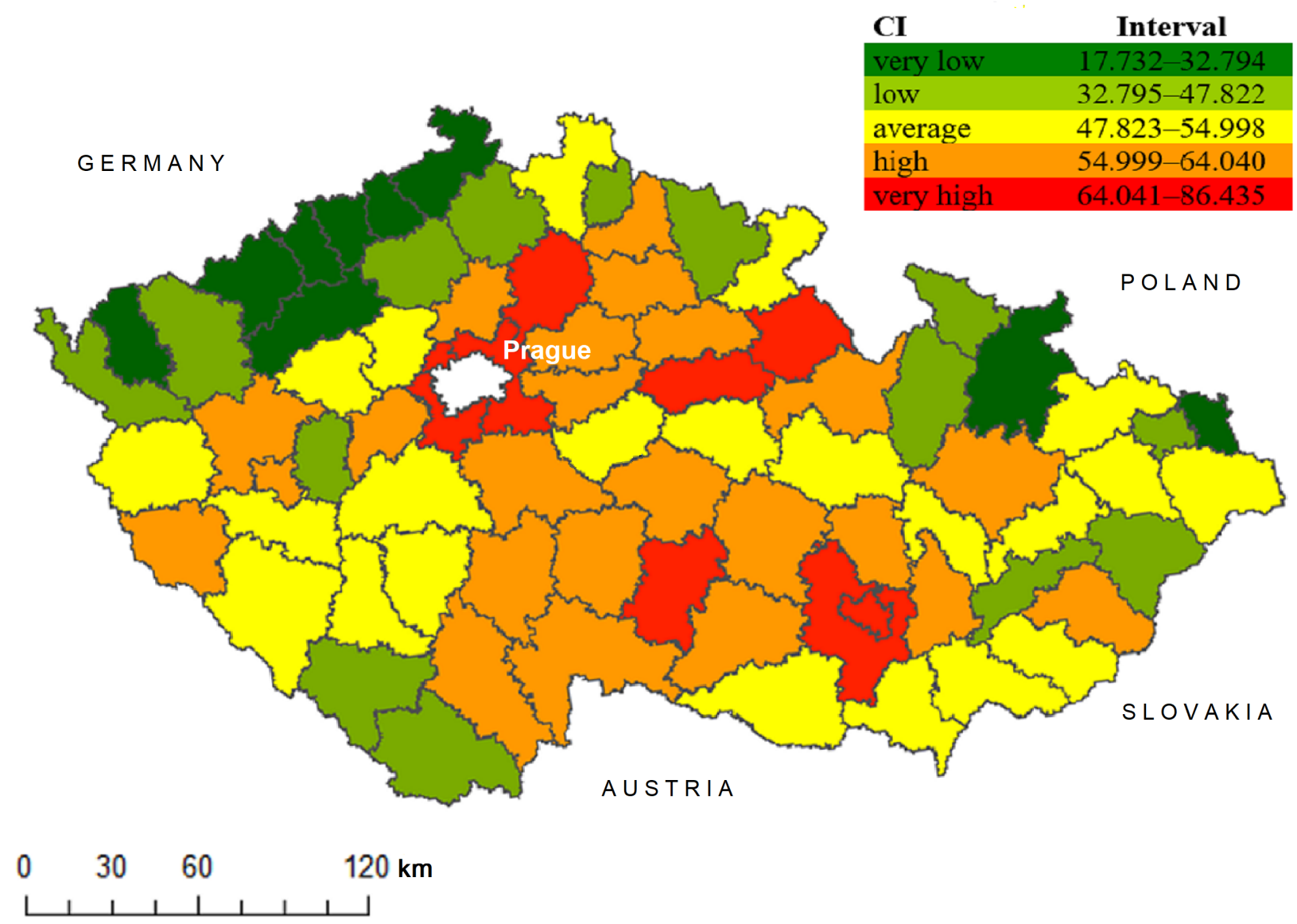

Fig. 1 Territorial differences in the value of the demographic and socio-economic index in the period from 2007 to 2018

The second group is made up by districts with low CI, which lie mainly in the border periphery of the Czech Republic. These are the following districts: Litoměřice, Česká Lípa, Jablonec nad Nisou, Trutnov, Karlovy Vary, Cheb, Český Krumlov, Prachatice, Ostrava-město, Jeseník, Šumperk, Zlín, Kroměříz and Rokycany. The average housing allowances here reach high values: in the district of Ostrava-město (CZK 1324/person) and Děčín (CZK 1263/person) and also the share of unemployed people is rather higher: the district of Děčín (9.4\%) and Ostrava-město (8.8\%). The share of university students shows unpropitious values: the district of Cheb (6.8\%) and Jeseník (7.9\%), as well as the infant mortality rate and the abortion rate. The infant mortality rate was $4.8 \%$ in the Cheb district and $4.2 \%$ in the Rokycany district, and the abortion rate reached $44.2 \%$ in the Česká Lípa district and $43.5 \%$ in Jablonec nad Nisou 45.5\%.

The third group includes districts with CI values achieving average results: Tachov, Klatovy, Plzeňjih, Strakonice, Písek, Př́bram, Kladno, Rakovník,
Liberec, Kutná Hora, Náchod, Svitavy, Chrudim, Prostějov, Přerov, Nový Jičín, Opava, Frýdek-Místek, Znojmo, Břeclav and Hodonín. In their territorial distribution, it is evident that they form an almost continuous strip of the so-called inner periphery of the Czech Republic, or they are a part of border districts. Housing allowances were average in the following districts: Přerov District (CZK 446/person) and Svitavy District (CZK 441/person). The highest share of unemployed people in this group was in the districts of Písek (4.9\%) and Svitavy $(7.4 \%)$, while the lowest share of universityeducated people was in the districts of Hodonín (8.9\%) and Frýdek-Místek (11.7\%). The age index in this group showed a predominance of seniors: the district of Liberec (103.5) and Rakovník (115.1). The fourth group consists of districts with high $\mathrm{CI}$ and includes the districts of České Budějovice, Jindřichův Hradec, Tábor, Pelhřimov, Benešov, Havlíčkův Brod, Ždár nad Sázavou, Blansko, Vyškov, Zlín, Olomouc, Ústí nad Orlicí, Plzeň-sever, Plzeňměsto, Beroun, Kolín, Nymburk, Hradec Králové, 
Jičín and Mělník. The share of the universityeducated population is relatively high in these districts: the district of Hradec Králové (14.2\%) and Zlín (12.8\%), the share of unemployed people is also positive: the district of Benešov (3.8\%) and Pelhřimov (4.4\%) and average duration of incapacity for work: Plzeň-město district (37.9 days) and Kolín (39.1 days). The age index represents the predominance of the senior groups: the Plzeñměsto district (135.3) and Olomouc (112.0).

The fifth group of districts belongs to the districts with the highest value of CI: Praha-východ, Praha-západ, Mladá Boleslav, Jihlava, Brno-město, Brno-venkov, Pardubice and Rychnov nad Kněžnou. Districts have a low average unemployment rate: Mladá Boleslav district (3.5\%) and Pardubice $(4.5 \%)$, a high share of university students: Brno město district (23.6\%) and Praha-západ (20.8\%), low infant mortality rates: district Prahavýchod $(1.3 \%)$ and Rychnov nad Kněžnou (1.9 $\%$ ) and low abortion rates: district Brno-venkov (23.3\%) and Praha-západ (24.9\%). This group is one of "the so-called" positive disparity of the Czech Republic (positive development impulse of the region, economic growth, low unemployment, high share of university students and favourable dynamics of regional development; Kutscherauer, 2008). The district of Praha-východ and Prahazápad has an exceptional position of demographic and socio-economic characteristics in the Czech Republic. The districts are located around the capital city of Prague and thus provide the main source of labour. The consequence of the suburbanization process is a significant increase in the number of inhabitants in these districts, and thus an aboveaverage migration balance (CZSO 2019b).

Table 3 Values of eigenvalues and interpretation of the dispersion of demographic and socio-economic indicators in the districts of the Czech Republic from 2007 to 2018

\begin{tabular}{crrrr}
\hline $\begin{array}{c}\text { Order } \\
\text { of } \\
\text { eigenvalue }\end{array}$ & Eigenvalue & $\begin{array}{c}\text { \% of } \\
\text { total } \\
\text { variance }\end{array}$ & $\begin{array}{c}\text { Cumulative } \\
\text { (eigenvalue) }\end{array}$ & $\begin{array}{c}\text { Cumulative } \\
\text { (\%) }\end{array}$ \\
\hline 1 & 4,48073 & 40,73394 & 4,480733 & 40,73394 \\
2 & 2,41786 & 21,98058 & 6,898597 & 62,71452 \\
3 & 1,37315 & 12,48318 & 8,271747 & 75,19770 \\
4 & 1,03017 & 9,36520 & 9,301919 & 84,56290 \\
\hline
\end{tabular}

The same input data as for the CI analysis were used for the cluster analysis. Based on the calculation of the main components of demographic and socio-economic indicators, which are based on the eigenvalues of the correlation matrix, it is evident that the eigenvalue higher than 1 was reported by four components (or factors). Their cumulative percentage reached $84.56 \%$ of the variability of the original variables (Table 3 ).

The table of factor burdens created a correlation structure, on the basis of which the four indicators with the highest burden were selected from each factor: indicator 1 housing allowances; indicator 2 average duration of incapacity for work; indicator 3 share of university students and indicator 4 age index (Table 4). These indicators were then used for cluster analysis.The division of districts into individual clusters was performed on the basis of the cluster schedule graph.

In order to facilitate the formulation of the characteristics of the formed clusters, an overview table (Table 5) and a graph of averages from several variables (Fig. 2) were used. The graph of the average (Fig. 2) was created on the basis of the classification of districts into clusters 1 to 9 (x-axis) and the average value of indicators, which is around the number 0.95 (y-axis). By breaking down the individual clusters according to the indicators used, it is possible to characterize the values in relation to the average and at the same time define regions with more suitable (cluster 1, 2, 3, 8 and 9) or less favourable (cluster 4, 5, 6 and 7) demographic and socio-economic factors affecting health inequalities.

Table 4 Factor loads after rotation of Varimax demographic and socio-economic indicators in districts of the Czech Republic from 2007 to 2018

\begin{tabular}{lcccc}
\hline & \multicolumn{5}{c}{ Factor burdens (Varimax simple) } \\
& \multicolumn{4}{c}{ Factor } \\
Variable/ Indicator & 1 & 2 & 3 & 4 \\
\hline $\begin{array}{l}\text { housing allowance } \\
\text { share of unemployed }\end{array}$ & $-0,16381$ & $-0,03542$ & $\mathbf{0 , 9 4 7 3 5}$ & 0,03155 \\
people & $-0,35577$ & 0,09441 & 0,71195 & 0,34953 \\
$\begin{array}{l}\text { average duration } \\
\text { of incapacity }\end{array}$ & 0,00874 & 0,180077 & 0,02056 & $\mathbf{0 , 9 0 8 6 9}$ \\
$\begin{array}{l}\text { for work } \\
\text { share of urban }\end{array}$ & 0,04772 & 0,134758 & 0,81666 & $-0,47101$ \\
$\begin{array}{l}\text { population } \\
\text { share of university } \\
\text { students } \\
\text { old age index }\end{array}$ & $\mathbf{0 , 9 3 5 2 1}$ & $-0,18840$ & 0,05468 & $-0,02514$ \\
$\begin{array}{l}\text { number of abortion } \\
\text { infant mortality }\end{array}$ & $-0,08303$ & $\mathbf{0 , 9 0 0 1 8}$ & $-0,00396$ & 0,01123 \\
$\begin{array}{l}\text { life expectancy } \\
\text { at birth }\end{array}$ & $-0,63643$ & $-0,16653$ & 0,53313 & $-0,32449$ \\
number of divorces & $-0,66189$ & 0,27571 & $-0,59465$ & $-0,18958$ \\
migration balance & 0,32426 & $-0,72713$ & $-0,46406$ & $-0,15260$ \\
\hline
\end{tabular}


Table 5 Cluster division and characteristics of demographic and socio-economic indicators in districts of the Czech Republic (average from 2007 to 2018)

\begin{tabular}{|c|c|c|}
\hline Cluster & Districts of CZR & Characteristics/ Area of concern \\
\hline 1 & Praha-východ, Praha-západ & $\begin{array}{l}\text { - above-average share of people with a university degree education } \\
\text { - below-average age index, housing allowances, days of incapacity } \\
\text { for work }\end{array}$ \\
\hline 2 & $\begin{array}{l}\text { Příbram, Jindřichův Hradec, } \\
\text { Písek, Tábor, Klatovy, Plzeň-jih, } \\
\text { Rokycany, Semily, Jičín, } \\
\text { Havlíčkův Brod, Pelhřimov, Přerov }\end{array}$ & $\begin{array}{l}\text { - below-average share of people with a university degree education, } \\
\text { housing allowances, days of incapacity for work } \\
\text { - average age index }\end{array}$ \\
\hline 3 & $\begin{array}{l}\text { Benešov, Bernou, Kolín, Mělník, } \\
\text { Mladá Boleslav, Nymburk, Domažlice, } \\
\text { Plzeň-sever, Rychnov nad Kněžnou, } \\
\text { Ústí nad Orlicí, Jihlava, Vyškov, Znojmo }\end{array}$ & $\begin{array}{l}\text { - average share of people with a university degree education and } \\
\text { all the other indices }\end{array}$ \\
\hline 4 & Děčín, Most, Karviná, Ostrava-město & $\begin{array}{l}\text { - above-average housing allowances } \\
\text { - below-average days of incapacity for work, share of university } \\
\text { graduates, old age index }\end{array}$ \\
\hline 5 & $\begin{array}{l}\text { Prachatice, Strakonice, Blansko, } \\
\text { Hodonín, Prostějov, Šumperk, Kroměříž, } \\
\text { Uherské Hradiště, Vsetín }\end{array}$ & $\begin{array}{l}\text { - above-average days of incapacity for work } \\
\text { - below-average share of people with a university degree } \\
\text { education, housing allowances } \\
\text { - average old age index }\end{array}$ \\
\hline 6 & $\begin{array}{l}\text { Karlovy Vary, Louny, Teplice, } \\
\text { Ústí nad Labem, Jablonec nad Nisou, } \\
\text { Náchod, Jeseník, Bruntál }\end{array}$ & $\begin{array}{l}\text { - above-average housing allowances } \\
\text { - below-average share of people with a university degree } \\
\text { education } \\
\text { - average days of incapacity for work, old age index }\end{array}$ \\
\hline 7 & $\begin{array}{l}\text { Kladno, Český Krumlov, Tachov, } \\
\text { Cheb, Sokolov, Chomutov, Česká Lípa, } \\
\text { Liberec }\end{array}$ & $\begin{array}{l}\text { - above-average housing allowances } \\
\text { - slightly below-average days of incapacity for work, share } \\
\text { of people with a university degree education, } \\
\text { - below-average old age index }\end{array}$ \\
\hline 8 & $\begin{array}{l}\text { Rakovník, České Budějovice, Litoměřice, } \\
\text { Trutnov, Chrudim, Svitavy, Třebíč, } \\
\text { Ždár nad Sázavou, Brno-venkov, Břeclav, } \\
\text { Olomouc, Zlín, Frýdek-Místek, Nový Jičín, } \\
\text { Opava }\end{array}$ & $\begin{array}{l}\text { - slightly above-average are only days of incapacity } \\
\text { for work } \\
\text { - other indices only average }\end{array}$ \\
\hline 9 & $\begin{array}{l}\text { Plzeň-město, Hradec Králové, } \\
\text { Pardubice, Brno-město }\end{array}$ & $\begin{array}{l}\text { - above-average share of people with a university } \\
\text { degree education, old age index } \\
\text { - below-average housing allowances } \\
\text { - below-average days of incapacity for work }\end{array}$ \\
\hline
\end{tabular}

The most heterogeneous cluster is cluster 1, which consists of the districts of Praha-východ and Prahazápad (Fig. 2). From the point of view of the evaluated indicators in relation to the health of the population, this cluster can be evaluated very positively. Cluster 2 consists of 12 districts, is also relatively homogeneous and shows positive subindicators of health. Cluster 3 is homogeneous and represented by 13 districts. In the third cluster, all monitored indicators are just below the average value, which, in addition to the share of persons with a university degree, can also be assessed as a favorable condition for the health of the population. A very homogeneous cluster of 8 forms 15 districts. This cluster has the assumptions of a relatively good state of health of the population in terms of the monitored indicators. Cluster 9 is composed of four districts and is relatively heterogeneous. The values of the monitored indicators and their variability from the average indicate suitable assumptions for the health of the population. 


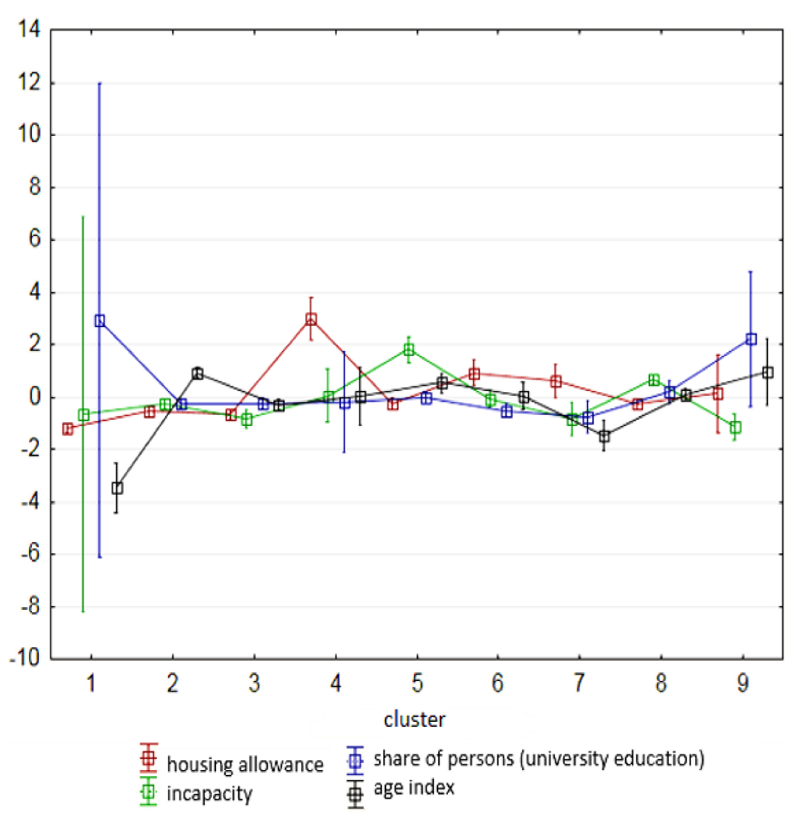

Fig. 2 Graph of the average of several variables for the interpretation of clusters of demographic and socio-economic indicators in the districts of the Czech Republic (average from 2007 to 2018)

Cluster 4 formed by four districts seems to be rather heterogeneous and the state of housing allowances and the share of university students indicates a certain socio-economic deprivation of districts. The situation is similar for cluster 5, which shows homogeneous features with unfavourable indicators for the possible emergence of health inequalities. Also in cluster 6, it can be assumed that worse demographic and socio-economic conditions may be reflected in the quality of population health. Homogeneous cluster 7 consists of eight districts and the values of housing allowances and the share of university students may indicate a lower quality of health.

\section{Summary of results}

Factors we call health determinants play a positive and negative role in the quality of population health and the health of individuals (Beaglehole in Barták 2010). Demographic factors tend to be linked to socio-economic environmental factors (poverty, education, social exclusion, unemployment, social security, family situation, etc.) and thus create a complex cause of health, leading to regional health inequalities (CSDH 2008; Cash-Gibson et al. 2018). Using analysis, the regional disparities of selected demographic and socio-economic indicators of the districts of the Czech Republic that can cause health inequalities were specified:

- Negative regional disparities (districts Most, Teplice, Děčín, Bruntál, Karviná, Ostravaměsto and Jeseník);

- Positive regional disparities (districts Prahazápad, Praha-východ, Mladá Boleslav, Jihlava and Brno-venkov).

High values of CI indicate a favourable state of the evaluated indicators of the following in the districts of the Czech Republic

- Praha-západ (86.4), Praha-východ $(81,8)$, Pardubice (70.3), Mladá Boleslav (70.2), Rychnov nad Kněžnou (66.5), Jihlava $(66,0)$, Brnoměsto (65.9), Brno-venkov (65.7), Žd’ár nad Sázavou (64.0) and Vyškov (62.4).

The given group of districts achieved a positive result (i.e. high CI) thanks to favourable partial values of demographic and socio-economic indicators (low housing subsidies, low unemployment, high ratio of university students, positive migration balance, low infant mortality and abortion rates). The best results are shown by the districts of Prague-východ and Prague-západ with positive regional disparities (favourable development impulse of the region, low unemployment, positive dynamics of regional development etc.; Kutscherauer 2008). Thanks to the proximity of the capital city of Prague, they occupy an exceptional position in the context of availability of job opportunities, and at the same time a better environment than in the urbanized zone of Prague itself. In line with the trend of suburbanization, these districts are attractive in terms of migration, especially for young families, thanks to which the age index is very low, above-average birth rates with low infant mortality (Hübelová et al. 2018; Hübelová \& Kozumplíková 2019). Low values of CI indicate a less favourable state of the evaluated indicators of the following in the districts of the Czech Republic:

- Ostrava-město (36.5), Sokolov (32.8), Ústí nad Labem (31.8), Bruntál (30.4), Louny (30.2), Karviná (29.1), Děčín (28.4), Chomutov (27.3), Teplice (23.6) and Most (17.7).

This group of districts achieved a rather undesirable result (i.e. low CI) due to negative values of demographic and socio-economic indicators (especially high housing subsidies, high unemployment, low ratio of university students, negative migration balance, high infant mortality and abortion rates). In summary, the area defined in this way can be described as negative regional disparities located mainly in the border periphery, which shows 
unfavorable economic, social and environmental development (structural impact of heavy industry, negative environmental impact, incidence of social exclusion, long-term unemployment, etc.; Kutscherauer et al. 2008).

The results of the cluster analysis of demographic and socio-economic indicators for the period 2007-2018 at the level of districts of the Czech Republic correspond to the results of the CI. The favourable situation of indicators for health quality was achieved by the cluster formed by the districts of Prague-východ and Prague-západ. At the same time, these districts show the greatest heterogeneity, i.e. the greatest difference in indicators in comparison with other districts of the Czech Republic. On the contrary, the situation in the cluster formed by the districts of Děčín, Most, Karviná and Ostrava-město proved to be the least favourable (Fig. 2).

\section{Discussion and conclusions}

To confirm the conclusions of our research, we determined the degree of influence of the examined socio-economic indicators on the basic causes of death (using factor analysis). This illustrates their relationship to the health status of the population, which we expressed by the structure of mortality: malignant neoplasms, diseases of the circulatory, respiratory and digestive system and external causes of death. It is clear from the results that there is: 1) a positive correlation between infant mortality, the share of abortions and mortality on diseases of respiratory system (especially the district of Bruntál, Sokolov, Tachov); 2) negative correlation between the share of the population with university education, life expectancy and mortality on diseases of the respiratory system (especially the district of Praha-východ, Prahazápad, Zlín, Mladá Boleslav); 3) correlation between housing allowances, the share of unemployed persons and mortality on external causes (e.g. Jeseník district); 4) correlation between the share of urban population, infant mortality, mortality on neoplasms and diseases of the respiratory system (eg district of Ostrava-město, Karviná, Most, Děčín) and 5) correlation between net migration, age index and mortality on diseases of the respiratory, circulatory and digestive system. The above results and dependencies of the examined indicators represent one of the possible approaches to examine the effects and impacts of demographic and socio-economic factors on regional health inequalities, however with awareness of certain limitations given by the choice of indicators. Their choice was given by deliberate selection based on other relevant researches. In developed countries, in connection with demographic aging, the proportion of seniors increases and with age the polymorbidity (i.e. the presence of several diseases at the same time) associated with the need for outpatient and inpatient care increases (Ramos et al. 2016). It is likely that as the population ages, the prevalence of chronic diseases will increase, especially cardiovascular disease, degenerative diseases of the nervous system, and an increase in cancer can also be expected (Vilinová \& Dubcová 2019; O’Connell et al. 2019).

In the Czech Republic, especially in the last 30 years, there has been a linear increase in life expectancy for both men and women, however the gender differences persist. The average life expectancy as well as its median is about six years lower in men than in women. Life expectancy has an increasing trend in all districts, although the pace is different and is influenced by the socioeconomic situation in the districts (Hübelová et al. 2021). The influence of socio-economic indicators on health is also proven by foreign studies. A Danish cohort study showed an association with the risk of miscarriage and educational level and income. These factors are most likely related to social status, environmental conditions and behaviour and may influence the risk of miscarriage (Norsker et al. 2012). Other studies have also reached similar conclusions, in which women with lower socioeconomic status, lower income, and education are indirectly at increased risk of miscarriage (Zheng et al. 2017). Similarly, the effect of unemployment levels and related changes in household expenses has been demonstrated (Bruckner et al. 2016). A study of Italian regions showed a strong dependence of infant mortality rates with relative and absolute income and unemployment rates (Dallolio et al. 2012).

The socio-economic causes and consequences of migration interact. In the case of the Czech Republic, the assessment of significance of the level of migratory mobility reflects, on one hand, development preconditions for regions with a dynamically developing economy; on the other hand can result in disruption of social relations and weakening of local identity and population health in the villages with transitory residency of its inhabitants (Ouredníček et al. 2011; Hübelová 2014).The spatial distribution of households receiving housing allowance is, proved not only by areas with a concentration of socioeconomically weaker population, but it is also possible to deduce spatial differentiation 
in household income (Ouředníček et al. 2011; Hübelová et al. 2018). This differentiation is also related to unemployment. In general, unemployment and lower levels of education are associated with poverty, poorer labour market opportunities, living in localities that are threatened by social pathology, violence or poor hygiene conditions (Čeledová \& Holčík 2018). People with higher education have a higher quality of health (Veugelers et al. 2001), prefer a healthy lifestyle, use seat belts, go for preventive check-ups and vaccinations, are also better informed and make better health choices, and it is these circumstances that reduce their mortality by up to 30\% (Kaikkonen et al. 2009; Hübelová et al. 2017). The level of educational attainment also affects the value of life expectancy increasing it by 10-20 years (Elo 2009).

It should also be considered that health is a multidimensional concept and that the effect of one variable can vary in these different dimensions. At the same time, the influence of factors on health is complicated by the fact that these variables correlate to each other to varying degrees, and therefore it is difficult to estimate the net effect of one variable (Miech \& Hauser 2001). In addition, the strength of the association between health and its factors varies throughout life (Chen et al. 2006). At present, in developed countries, including the Czech Republic, diseases dominate, which are mainly caused by lifestyle. These pose a serious health problem with all the other social and economic consequences, and it is therefore highly desirable to address the assessment of the factors that may affect health inequalities and their regional disparities. Such inequalities in health can then be prevented by appropriate means in various policy and health measures, but also in society in general.

\section{Acknowledgements}

This work was supported by a Faculty of Regional Development and International Studies Mendel University in Brno "Health status index as a way of promoting equality and reducing regional disparities in the Czech Republic", FRRMS IGA 2019/017.

\section{References}

Barták, M (2010) Ekonomika zdraví: sociální, ekonomické a právní aspekty péče o zdraví. Wolters Kluwer Česká republika, Praha.

Börsch-Supan A, Brandt M, Hunkler C, Kneip T, Korbmacher J, Malter F, Zuber S (2013) Data Resource Profile: The Survey of Health, Ageing and Retirement in Europe (SHARE). International Journal of Epidemiology 42(4): 992-1001.

Bruckner T, Mortensen L, Catalano R (2016) Spontaneous Pregnancy Loss in Denmark Following Economic Downturns. American Journal of Epidemiology 183(8): 701-708

Bültmann U, Siegrist J (eds) (2020) Handbook of Disability, Work and Health. Springer International Publishing.

Burcin B, Kučera T (2004) Perspektivy populačního vývoje České republiky na období 2003-2065. DemoArt, Praha.

Cash-Gibson L, Rojas-Gualdro'n DF, Pericàs JM, Benach J (2018) Inequalities in global health inequalities research: A 50-year bibliometric analysis (1966-2015). PLoS ONE 13(1).

Čeledová L, Holčík J (2018) Sociální lékařství a veřejné zdravotnictví pro studenty zubního lékařství. Praha: Univerzita Karlova, nakladatelství Karolinum.

Chen E, Andrew D, Matthews K (2006) Socioeconomic status and health: Do gradients differ within childhood and adolescence? Social Science \& Medicine 62(9): 2161-2170.

Chung RY, Griffiths SM (2018) Migration and health in the world: a global public health perspective. Public Health 158: 64-65.

CSDH (2008) Closing the gap in a generation: Health equity through action on the social determinants of health. Final Report of the Commission on Social Determinants of Health, Geneva.

CZSO (2019a) Zemřelí podle seznamu př́čin smrti, pohlaví a věku v CR, krajích a okresech - 2009 až 2018. C CUÚ, Praha. Available from: <https://www.czso.cz/csu/czso/ceska-republikapodle-pohlavi-a-veku-2008-2017-b1c67xq334>

CZSO (2019b) Obyvatelstvo - roční časové řady (Pohyb obyvatelstva v Českých zemích 1785 - 2018, (relativní údaje). ČSÚ, Praha. Available at: <https://www.czso.cz/csu/czso/obyvatelstvo_hu>

Cutler D M, Lleras-Muney A (2006) Education and Health: Evaluating Theories and Evidence. National Bureau of Economic Research (NBER) Working Paper No. 12352.

Dallolio L, Di Gregori V, Lenzi J, Franchino G, Calugi S, Domenighetti G, Fantini MP (2012) Socio-economic factors associated with infant mortality in Italy: an ecological study. International Journal for Equity in Health 11: 45.

Demir-Dagdas T (2020) Parental Divorce, Parent-Child Ties, and Health: Explaining Long-Term Age Differences in Vulnerability. Marriage and Family Review.

EC (2013) Report on health inequalities in the European Union. Commission staff working document, Brussels.

Elo I (2009) Social class differentials in health and mortality: Patterns and explanations in comparative perspective. Annual Review of Sociology 35: 553-572.

Fraser S D S, George S (2015) Perspectives on differing health outcomes by city: Accounting for Glasgow's excess mortality. Risk Management and Healthcare Policy 8: 99-110.

Giles-Corti B, Vernez-Moudon A, Reis R, Turrell G, Dannenberg A L, Badland H, Foster Set al. (2016) City planning and population health: a global challenge. Lancet 388(10062): 2912-2924. 


\section{sciendo}

Ho J Y, Hendi A S (2018) Recent trends in life expectancy across high income countries: retrospective observational study. BMJ 362 (k2562):1-14.

Holčík J, Káňová P, Prudil L (2015) Systém péče o zdraví a zdravotnictví: východiska, základní pojmy a perspektivy. Národní centrum ošetřovatelství a nelékařských zdravotnických oborů, Brno.

Hübelová D (2014) Geodemografická analýza kvality lidských zdrojů v České republice. Mendelova univerzita v Brně.

Hübelová D, Jadczaková V, Rousová G (2017) Vliv demografických a socioekonomických determinantů na úmrtnost v okresech Jihomoravského kraje v letech 2006-2015. In: XX. Mezinárodní kolokvium o regionálních vědách: sborník příspěvků. Masarykova univerzita, Brno, pp. 396-405.

Hübelová D, Kozumplíková A, Jadczaková V, Rousová G (2018) Spatial differentiation of selected health factors of the South Moravian Region population. Geographia Cassoviensis 12(1): 34-52.

Hübelová D, Kozumplíková A (2019) Evaluation of Demographic and Socio-economic Factors of Mortality in the South Moravian Region (Czech Republic). Acta Universitatis agriculturae et silviculturae Mendelianae Brunensis 67(5): 1255-1267.

Hübelová D, Kozumplíková A, Walicová V (2020a) Mortality Structure of Populations, Demographic and Socio-Economic Situation in European Union Countries: Development and Differ entiation in the Period 2011-2014. European Spatial Research and Policy 27(2): 173-193.

Hübelová D, Kozumplíková A, Kosová P, Walicová V (2020b) Relationship between Socio-demographic and Economic Determinants of Cause-Specific Mortality in the EU Countries in the Period 2011-2014. Geographia Cassoviensis XIV(2): 120-143.

Hübelová D, Chromková-Manea B E, Kozumplíková A (2021) Zdraví a jeho sociální, ekonomické a environmentální determinanty: teoretické a empirické vymezení. Sociológia 53(2), in press.

Kaikkonen R, Rahkonen O, Lallukka T, Lahelma E (2009) Physical and psychosocial working conditions as explanations for occupational class inequalities in self-rated health. European Journal of Public Health 19(5): 458-463.

Kawachi I, Subramanian SV, Almeida-Filho N (2002) A glossary for health inequalities. Journal of Epidemiology and Community Health, 56(9): 647-652.

Kutscherauer A (2008) Regionální disparity - jejich pojetí, klasifikace a měření. VŠB - Technická univerzita Ostrava.

Lakes T, Brückner M, Krämer A (2014) Development of an environmental justice index to determine socio- economic disparities of noise pollution and green space in residential areas in Berlin. Journal of Environmental Planning and Management 57(4): 538-556.

Lalonde M (1974) A new perspective on the health of Canadians. Ottawa, ON: Minister of Supply and Services Canada. Available at: <http://www.phac-aspc.gc.ca/ph-sp/pdf/perspect-eng.pdf>

Landrigan P J, Fuller R, Acosta N J R, Adeyi O, Arnold R, Basu N N, Balde A B, Bertollini R, Bose-O'Reilly S, Boufford J I et al. (2018) The Lancet Commission on pollution and health. Lancet. 391(10119): 462-512.

Li X, Song J, Lin T, Dixon J, Zhang G, Ye H (2016) Urbanization and health in China, thinking at the national, local and individual levels. Environ Health 15 Suppl 1: 32.

Ljungdahl S, Bremberg, S G (2015) Might extended education decrease inequalities in health? - A meta-analysis. European Journal of Public Health 25(4): 587-592.
Mareš P (1999) Sociologie nerovnosti a chudoby. Praha. Sociologické nakladatelství.

Marmot M, Bell, R (2012) Fair society, healthy lives. BMC Public Health 126(1): 4-10.

Matějů P, Kreidl M (1998) Rekonstrukce sociální statusu. Sociální trendy. Sociologický ústav Akademie věd České republiky, pracovní texty výzkumného projektu „Sociální trendy” 3/1998.

Meloun M, Militký J, Hill M (2017) Statistická analýza vícerozměrných dat v př́kladech. Univerzita Karlova, nakladatelství Karolinum, Praha.

Miech R A, Hauser R M (2001) Socioeconomic Status and Health at Midlife: A Comparison of Educational Attainment with Occupation-Based Indicators. Annals of Epidemiology 11(2): 75-84.

Minařík B, Borůvková J, Vystrčil M (2013) Analýzy v regionálním rozvoji. Professional Publishing, Praha.

Minicuci N, Naidoo N, Chatterji S, Kowal P (2016) Data Resource Profile: Cross-national and cross-study sociodemographic and health-related harmonized domains from SAGE plus ELSA HRS and SHARE (SAGE+, Wave 1). International Journal of Epidemiology 48(1): 14-14.

Mirowsky J, Ross C E (2003) Education, Social Status, and Health. De Gruyter, New York.

Norsker FN, Espenhain L, a' Rogvi S, et al. (2010) Socioeconomic position and the risk of spontaneous abortion: a study within the Danish National Birth Cohort. BMJ Open. Available at: <http://bmjopen.bmj.com/>

Norstrom F, Waenerlund A K, Lindholm L, Nygren R, Sahlen K G, Brydsten A (2019) Does unemployment contribute to poorer health-related quality of life among Swedish adults? BMC Public Health 19(457)

O'Connell M D L, Marron M M, Boudreau R M, Canney M, Sanders J L, Kenny, R A et al. (2019) Mortality in Relation to Changes in a Healthy Aging Index: The Health, Aging, and Body Composition Study. The Journals of Gerontology: Series A. 74(5): 726-732.

OECD 2008: Handbook on constructing composite indicators: methodology and user guide. Paris (OECD). Available from: <http://www.oecd.org/std/42495745.pdf>

Ottersen O P, Dasgupta J, Blouin C, Buss P, Chongsuvivatwong $\mathrm{V}$, Frenk J, et al. (2014) The political origins of health inequity: prospects for change Lancet 383: 630-667.

Ouředníček M, Temelová J, Pospíšilová L eds (2011) Atlas of Socio-spatial Differentiation of the Czech Republic. Karolinum, Praha.

Pinto D A, Glattstein-Young G, Mohamed A, Bloch G, Leung F R H Glazier, R H (2016) Pruchno R A, Wilson-Genderson M, Rose M, Cartwright, F (2010) Successful aging: early influences and contemporary characteristics. The Gerontologist 50: 821-833.

Ramos L R, Tavares N U L, Bertoldi A D, Farias M R, Oliveira M A, Luiz V L et al. 2016. Polypharmacy and Polymorbidity in Older Adults in Brazil: a public health challenge. Revista Saude Publica. 50 (suppl 2): 9.

Saks M, Allsop J (2013) Researching Health Qualitative, Quantitative and Mixed Methods. SAGE Publications, Los Angeles.

Sbarra D A (2015) Divorce and Health: Current Trends and Future Directions. Psychosomatic Medicine 77(3): 227-236.

Son J Y, Lee J T (2011) The effect of sociodemographic factors on infant mortality according to cause of death: a birth cohort in Seoul, Korea, 1999-2003. International Journal of Public Health 56(1): 7-13. 


\section{S sciendo}

Srivarathan A, Jensen A N, Kristiansen M (2019) Communitybased interventions to enhance healthy aging in disadvantaged areas: perceptions of older adults and health care professionals. BMC Health Services Research 19(7).

Tavares A I (2017) Infant mortality in Europe, socio-economic determinants based on aggregate data. Applied Economics Letters 24(21): 1588-1596.

Tomulic K L, Mestrovic J, Zuvic M, Rubelj K, Peter B, Cace I B, Verbic A (2017) Neonatal risk mortality scores as predictors for health-related quality of life of infants treated in NICU: a prospective cross-sectional study. Quality of Life Research 26(5): 1361-1369.

Tuček, M (ed.) (2008) Soudržnost v diferencující se společnosti. Sociologický ústav AV ČR, Praha.

Večerník J, Matějů P (1998) Zpráva o vývoji české společnosti 1989-1998. Academia, Praha.
Veugelers P, Yip A, Kephart G (2001) Proximate and contextual socioeconomic determinants of mortality: multilevel approaches in a setting with universal health care coverage. American Journal of Epidemiology 154: 725-732.

Vilinová K, Dubcová A (2019) Analysis of Mortality from Cancer in the Regional Context of Slovakia. Geographia Cassoviensis 13(1): 83-101.

Zenger M, Berth H, Brähler E, Stöbel-Richter Y (2013) Health Complaints and Unemployment: The Role of Self-Efficacy in a Prospective Cohort Study. Journal of Social and Clinical Psychology 32(1): 97-115.

Zheng D, Li Ch, Wu T, Tang (2017) Factors associated with spontaneous abortion: a cross-sectional study of Chinese populations. Reproductive Health 14: 33 .

Zulkarnain A, Korenman S (2019) Divorce and health in middle and older ages. Review of Economics of the Household 17(4): 1081-1106. 